\title{
Tyrosine phosphorylation regulates ER $\beta$ ubiquitination, protein turnover, and inhibition of breast cancer
}

\author{
Bin Yuan ${ }^{1,2,3, *}$, Long Cheng ${ }^{1, *}$, Kshama Gupta ${ }^{3}$, Huai-Chin Chiang ${ }^{3}$, Harshita B. Gupta ${ }^{4}$, \\ Gangadhara R. Sareddy ${ }^{5}$, Degeng Wang ${ }^{6, \#}$, Kate Lathrop ${ }^{4}$, Richard Elledge ${ }^{4}$, \\ Pei Wang7, Stanton McHardy ${ }^{8}$, Ratna Vadlamudi, Tyler J. Curiel ${ }^{4}$, Yanfen $\mathbf{H u}^{3}$, \\ Qinong $\mathbf{Y e}^{1,2}$, Rong $\mathbf{L i}^{3}$ \\ ${ }^{1}$ Department of Medical Molecular Biology, Beijing Institute of Biotechnology, Collaborative Innovation Center for Cancer \\ Medicine, Beijing, China \\ ${ }^{2}$ Institute of Cancer Stem Cell, Cancer Center, Dalian Medical University, Liaoning, China \\ ${ }^{3}$ Department of Molecular Medicine, University of Texas Health Science Center at San Antonio, San Antonio, TX, USA \\ ${ }^{4}$ Department of Medicine, University of Texas Health Science Center at San Antonio, San Antonio, TX, USA \\ ${ }^{5}$ Department of Obstetrics and Gynecology, University of Texas Health Science Center at San Antonio, San Antonio, TX, USA \\ ${ }^{6}$ Department of Epidemiology and Biostatistics, University of Texas Health Science Center at San Antonio, San Antonio, TX, USA \\ ${ }^{7}$ Department of Cellular and Structural Biology Cancer Therapy and Research Center, University of Texas Health Science \\ Center at San Antonio, San Antonio, TX, USA \\ ${ }^{8}$ Center for Innovative Drug Discovery, University of Texas at San Antonio, San Antonio, TX, USA \\ *These authors have contributed equally to this work \\ \#Present address: The Institute of Environmental and Human Health, Texas Tech University, Lubbock, TX, USA \\ Correspondence to: Rong Li, email: lir3@uthscsa.edu \\ Qinong Ye, email: yeqn@nic.bmi.ac.cn \\ Keywords: tyrosine phosphorylation, ERß, ubiquitination, antitumor activity, protein turnover
}

Received: November 22, $2015 \quad$ Accepted: May 23, $2016 \quad$ Published: June 14, 2016

\section{ABSTRACT}

Unlike estrogen receptor $\alpha(E R \alpha)$ that predominantly promotes hormonedependent breast tumor growth, ER $\beta$ exhibits antitumor effects in a variety of cancer types. We recently identified a phosphotyrosine residue in ERB, but not ERa, that dictates ER $\beta$ transcriptional activity and antitumor function. We show here that this ER isotype-specific phosphotyrosine switch is important for regulating ER $\beta$ activity in cell proliferation, migration, and invasion. At the mechanistic level, phosphorylated $E R \beta$, which recruits transcriptional coactivator p300, is in turn targeted by p300 for ubiquitination and proteasome-dependent protein turnover. Furthermore, ER $\beta$ specific agonists such as S-equol enhance ERß phosphorylation, suggesting a crosstalk between ligand- and posttranslational modification-dependent ER $\beta$ activation. Inhibition of xenograft tumor growth by $\mathbf{S}$-equol is associated with reduced tumor Ki-67 expression and elevated ER $\beta$ tyrosine phosphorylation. Taken together, our data support the notion that phosphotyrosine-dependent ER $\beta$ signaling is an attractive target for anticancer treatment.

\section{INTRODUCTION}

The diverse physiological and pathological effects of estrogens are mediated by two estrogen receptors, ER $\alpha$ and ER $\beta$, which are encoded by different genes (ESRI and ESR2) [1]. Although these two ER isotypes share homologous protein sequence and similar transcriptional activity, they exhibit quite distinct biological functions in cancer development and progression. $\mathrm{ER} \alpha$ is well documented for its role in promoting estrogen-dependent breast tumorigenesis, whereas ER $\beta$ has been reported to inhibit tumor growth in multiple cancer types including breast and ovarian cancers, melanoma, and glioma [1-7]. In addition to common target genes shared by these two ER isotypes, $E R \beta$ binds to its own transcriptional target genes through either estrogen response elements (ERE) or by tethering to other DNA-binding transcription factors [8-19]. The ER $\alpha$-independent activity of ER $\beta$ represents 
a prevailing mode of ER $\beta$ action in ER $\alpha$-negative cancers. In ER $\alpha$-positive cancer cells, ER $\beta$ is also capable of interfering with ER $\alpha$ activity through hetero-dimerization and/or competition for common binding sites $[6,14,15$, 20-30], thus making ER $\beta$ a partial dominant negative receptor for $\mathrm{ER} \alpha[23,24,31]$. Clearly, $\mathrm{ER} \beta$ functions in transcription and cancer are different from those of ER $\alpha$.

The disparate functional outcomes of the ER $\alpha$ and $\mathrm{ER} \beta$ actions are at least partly due to differences in protein structure between these two ER subtypes. Despite a highly homologous central DNA binding domain (DBD, 96\% identity) and carboxyl (C)-terminal ligand-binding domain (AF2 + LBD, 53\% identity), the amino (N)-terminal sequence (AF1, 18\% identity) is quite divergent between these two ER subtypes. This AF1 domain has been linked to subtype-specific transcription activity of $\operatorname{ER} \beta[32,33]$. Furthermore, we recently discovered that an ER $\beta$-specific phosphotyrosine residue in the AF1 domain of ER $\beta$ (pY36) dictates the antitumor activity of ER $\beta$ [34]. This tyrosine residue is highly conserved in all mammalian ER $\beta$ orthologs, but not in ER $\alpha$ (alanine in ER $\alpha$ ). Our published work shows that mutation of Y36 to phenylalanine (YF) obliterates ligand-dependent transcription and ER $\beta$ antitumor activity in ER $\alpha$-negative breast cancer [34]. Of note, ER $\beta$ phosphorylation status strongly correlates with longer survival in breast cancer patients [34]. Thus, this newly identified phosphotyrosine switch offers a potential opportunity to fine-tune ER $\beta$ biological activity in cancer with precision and potency.

In the current work, we investigated the influence of the phosphotyrosine switch on tumor cell proliferation, migration, and invasion. In addition, we determined how abundance of phosphorylated ER $\beta$ protein was regulated in cancer cells. Finally, we found that the ER $\beta$-specific agonist S-equol induced ER $\beta$ phosphorylation and inhibited tumor growth in vitro and in vivo. Our study lends further support to the notion that turning on the phosphotyrosine switch in ER $\beta$ is important for mobilizing its antitumor activity.

\section{RESULTS}

\section{The phosphotyrosine switch is important for antiproliferative activity of ERß}

Our published work demonstrates that the ER $\beta$ phosphotyrosine switch regulates antitumor activity of $\mathrm{ER} \beta$ in triple negative breast cancer $\left(\mathrm{ER} \alpha^{-} / \mathrm{PR}^{-} /\right.$ HER2-) [34]. To determine the generalizability of our previous conclusion, we introduced both wild-type (WT) ER $\beta$ and the functionally inactive tyrosine-tophenylalanine (Y36F) mutant into ER $\alpha$-positive breast cancer cells (MCF7), ovarian cancer cells (SKOV3), and glioblastoma cells (U87), which represent three cancer types where ER $\beta$ antitumor activity had been previously demonstrated $[1,4,35]$. Consistent with the previous reports, WT ER $\beta$ significantly reduced tumor cell viability in all three tumor cell lines (Figure 1A-1B, Supplementary Figure 1). In contrast, cells expressing the Y36F mutant exhibited little suppression of cell viability, suggesting that the phosphorylation switch is required for ER $\beta$ antiproliferative activity in multiple tumor cell types. In addition to cell proliferation, ER $\beta$ can inhibit cell migration and invasion [36]. In this regard, we found that ER $\beta$-mediated inhibition of both tumor cell migration and invasion were significantly compromised by the $\mathrm{Y} 36 \mathrm{~F}$ mutation in MCF7 cells (Figure 1C-1D), thus implicating a role of the phosphotyrosine switch in multiple aspects of ER $\beta$ mediated antitumor function.

\section{pY36 facilitates coactivator-dependent ubiquitination and turnover of ER $\beta$}

Emerging evidence from studies of eukaryotic transcription suggests a mechanistic coupling between transcriptional activation and ubiquitin-dependent degradation of transcription activators by proteasomes $[37,38]$. Consistent with such a notion, AF1 of ER $\beta$ has been implicated in ER $\beta$ ubiquitination and proteasomemediated degradation [39, 40]. We therefore asked whether pY36 played a role in transcription-coupled $\operatorname{ER} \beta$ ubiquitination and turnover. Our previous work indicated that the transcription coactivator p300 is recruited to ER $\beta$ target promoters, including that of MDA7, by ER $\beta$ in a pY36-dependent manner [34]. Here we found that ectopic expression of p300 promoted ligand-dependent transcriptional activation of ER $\beta$-specific target gene MDA7 by ectopic ER $\beta$ in HEK293T cells (Figure 2A), whereas siRNA-mediated p300 knockdown blunted ER $\beta$ activity (Figure 2B). These data further confirm functional importance of p300 in potentiating ER $\beta$ transcriptional activity. Given the previously reported E4 ubiquitin ligase activity of p300 [41], we used an in vitro ubiquitination assay to assess the ability of p300 to ubiquitinate ER $\beta$. In the presence of ubiquitin and E1/E2 ubiquitin ligases, ER $\beta$ was ubiquitinated by p300 expressed in mammalian cells, but not bacteria (lanes 4 and 5, Figure 2C). This could be due to posttranslational modification of p300 in mammalian cells required for ER $\beta$ ubiquitination. Alternatively, the observed ER $\beta$ ubiquitination could result from the combined action of p300 E4 and a coimmuniprecipitated E3 ubiqutin ligase. We next examined the effect of p300 on ER $\beta$ ubiquitination in vivo. We found that p300 knockdown substantially reduced the extent of Flag-tagged ER $\beta$ ubiquitination (compare lanes 2 and 4 in Figure 2D). Furthermore, WT ER $\beta$ was ubiquitinated more extensively than the Y36F mutant (compare lanes 2 and 6 in Figure 2D). This result strongly suggests that the phosphotyrosine switch promotes $\mathrm{p} 300$-mediated ER $\beta$ ubiquitination. 
Consistent with a role of proteasome-dependent regulation in ER $\beta$ protein turnover, we reproducibly observed stabilization of Flag-tagged WT ER $\beta$ by the treatment of proteasome inhibitor MG132 (compare lanes 1 and 2 in Figure 2D). To directly compare the half-life of WT and mutant ER $\beta$ protein, we assessed their abundance in the presence of the protein synthesis inhibitor cycloheximide. The Y36F mutant was substantially more stable (half-life $>8$ hours, Figure 3A$3 \mathrm{~B})$ than its WT counterpart (approximately 1 hour). In a parallel experiment, p300 knockdown also significantly extended WT ER $\beta$ half-life (Figure 3C-3D). Together with our previous findings of $\mathrm{pY} 36$-dependent promoter recruitment of p300 by ER $\beta$, our current data strongly indicate that the phosphotyrosine switch promotes two reciprocal events in ER $\beta$-mediated transcriptional activation: p300 recruitment by ER $\beta$ and subsequent p300dependent destruction of ER $\beta$.

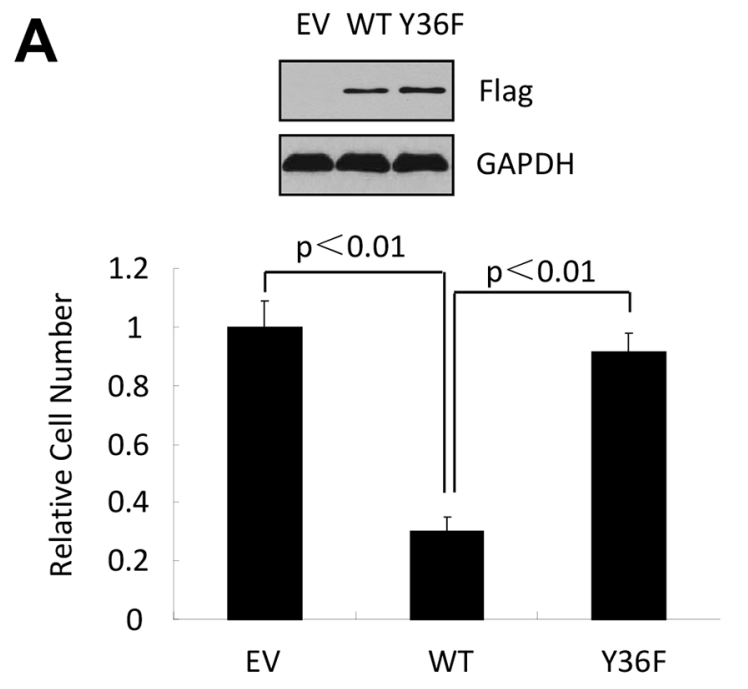

C

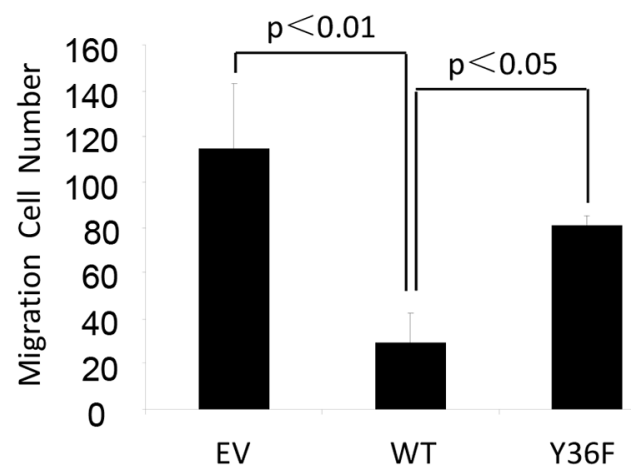

\section{Endogenous ER $\beta$ exhibits antitumor activity}

$E R \beta$ is expressed in a significant percentage of breast tumors across all subtypes [42, 43], making it a potential target in anticancer therapies. In addition, several natural and synthetic ER $\beta$-selective agonists were well tolerated in clinical trials [44] (ClinicalTrials. gov), further elevating therapeutic feasibility of rallying $\operatorname{ER} \beta$ antitumor activity. However, before any ER $\beta$ targeting therapeutic agents are to be further explored for their clinical utility, it is important to verify their dependence on the presumed therapeutic target. To this end, we used CRISPR-Cas 9 to knock out ER $\beta$ in triplenegative breast cancer cells MDA-MB-231. Several out-of-frame mutant clones were identified, two of which were selected for functional studies. The two clones contain an insertion of nucleotide "A" (Mut1) and deletion of "ACAA" (Mut2), respectively, at the

B

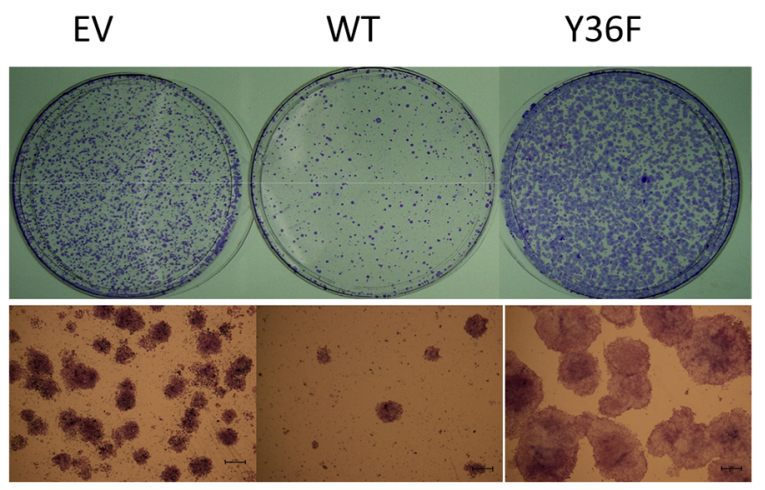

D Cell Invasion

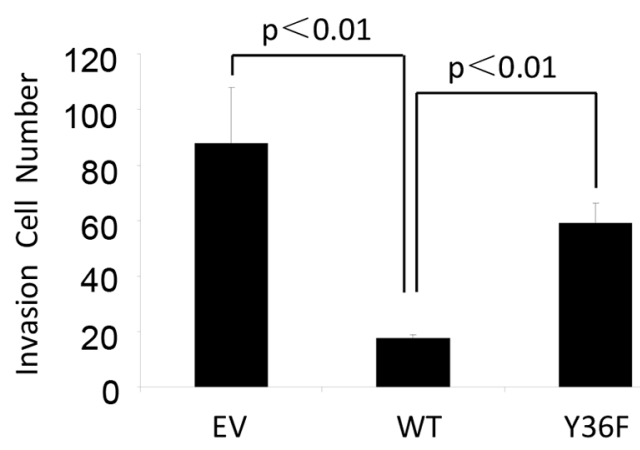

Figure 1: The phosphotyrosine switch is important for ER $\boldsymbol{\beta}$ activity in multiple cancer types. A. In vitro MTT assay using MCF7-derived breast cancer cells that contained empty vector, WT, or Y36F mutant ER $\beta$. Western blot of Flag-ER $\beta$ proteins in MCF7 stable cell lines. B. WT but not Y36F mutant ER $\beta$ overexpression in MCF7 cells reduced colony formation. C. and D. WT but not Y36F mutant ER $\beta$ overexpression reduced cell migration (C) and invasion (D). Data here and elsewhere represent average of at least three biological duplicates. Error bars indicate s.e.m. 
engineered double strand break in the first proteincoding exon of the ESR2 locus (Supplementary Figure $\mathrm{S} 2 \mathrm{~A})$. Depletion of ER $\beta$ protein in both cell clones was confirmed by immunoblotting (Figure 4A and Supplementary Figure S2B).The resulting knockout cells grew significantly faster than the isogenic ER $\beta$ expressing cells (Figure 4B-4C, Supplementary Figure $\mathrm{S} 2 \mathrm{C}$ ). In both Boyden chamber and wound-healing assays, the knockout cells also exhibited enhanced migratory ability versus the control cells (Figure 4D4E). Furthermore, compared to the parental cells, ER $\beta$ knockout cells were more refractory to a previously characterized ER $\beta$-selective agonist S-equol [18] (Figure 4F), thus supporting the selectivity of the ER $\beta$ targeting compound.
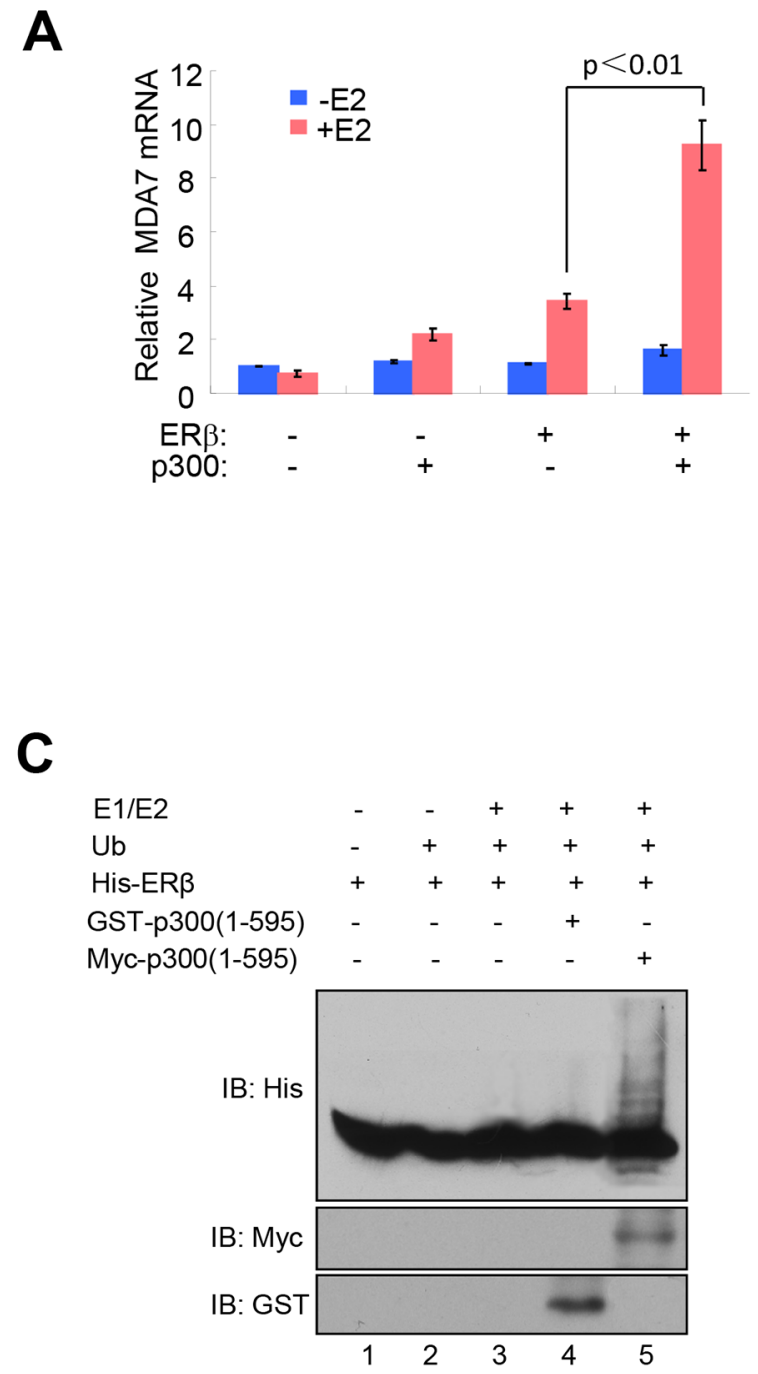

\section{S-equol stimulates pY36 and inhibits tumor growth in vivo}

To explore the translational potential of the ER $\beta$ phosphotyrosine switch, we asked whether ER $\beta$ ligand could alter the pY36 status. As shown in Figure 5A, Y36-specific ER $\beta$ phosphorylation was enhanced by the $\mathrm{ER} \alpha / \mathrm{ER} \beta$ common agonist $17 \beta$-estradiol and two ER $\beta$ specific agonists DPN and S-equol, suggesting a crosstalk between the $\mathrm{C}$-terminal ligand-binding domain and $\mathrm{N}$-terminal phosphorylation site of ER $\beta$. Furthermore, in a xenograft tumor model, S-equol inhibited MDA-MB-231 cell-derived tumor growth (Figure 5B), accompanied by significant reduction in the number of tumor cells expressing Ki-67, an established marker for cycling cells (Figure 5C), and with concomitant increase in pY36 signal

B
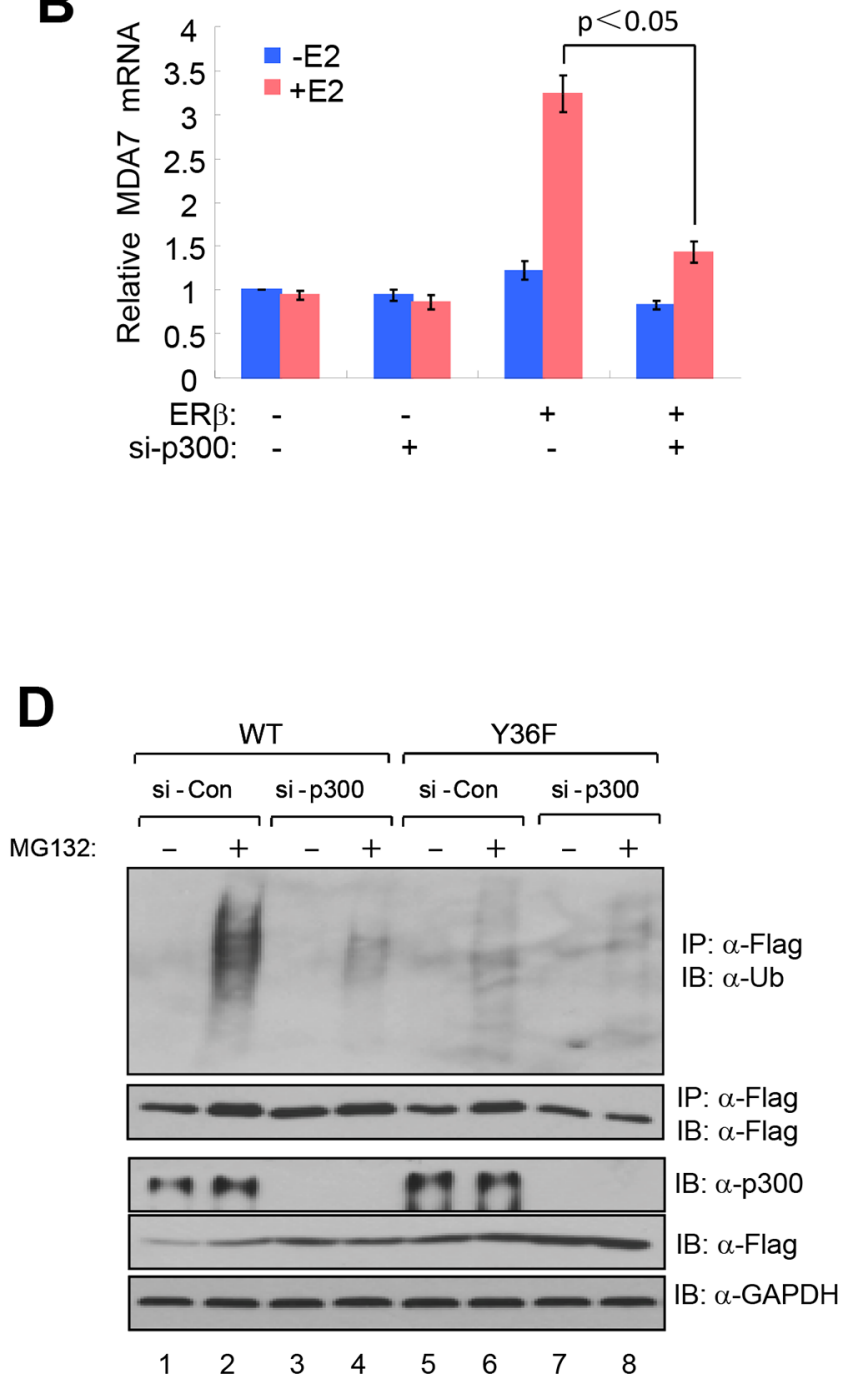

Figure 2: pY36 facilitates coactivator-dependent ubiquitylation and turnover of ERß. A. Ectopic expression of p300 promoted ligand-dependent transcriptional activation of MDA7 by ectopic ER $\beta$ in HEK293T cells. B. siRNA-mediated p300 knockdown blunted ectopic ER $\beta$ activity in HEK293T cells. C. In vitro ubiquitination assay containing E1/E2 ubiquitin ligases, purified bacterially expressed His-ER $\beta$, bacterially expressed GST-p300(1-595) or mammalian cell-expressed myc-p300(1-595). D. p300 knockdown substantially reduced the extent of ER $\beta$ ubiquitination in HEK293T cells. 
in xenografted tumors (Figure 5D). This in vivo finding provides additional supporting evidence for a tumorintrinsic function of the ER $\beta$ phosphotyrosine switch in therapeutic response to ER $\beta$-activating compounds.

\section{DISCUSSION}

Mobilization of ER $\beta$ antitumor activity is an attractive therapeutic strategy. Our current study bolsters the concept that rallying the antitumor activity of $\operatorname{ER} \beta$ through its phosphotyrosine switch is applicable to both ER $\alpha$-positive and -negative tumor cells of various cancer types. While our work focuses on the phosphotyrosine switch in full-length ER $\beta$ (ER $\beta 1)$, we are aware of ER $\beta$ splicing variants (ER $\beta 2-5)$, which share the same ER $\beta$
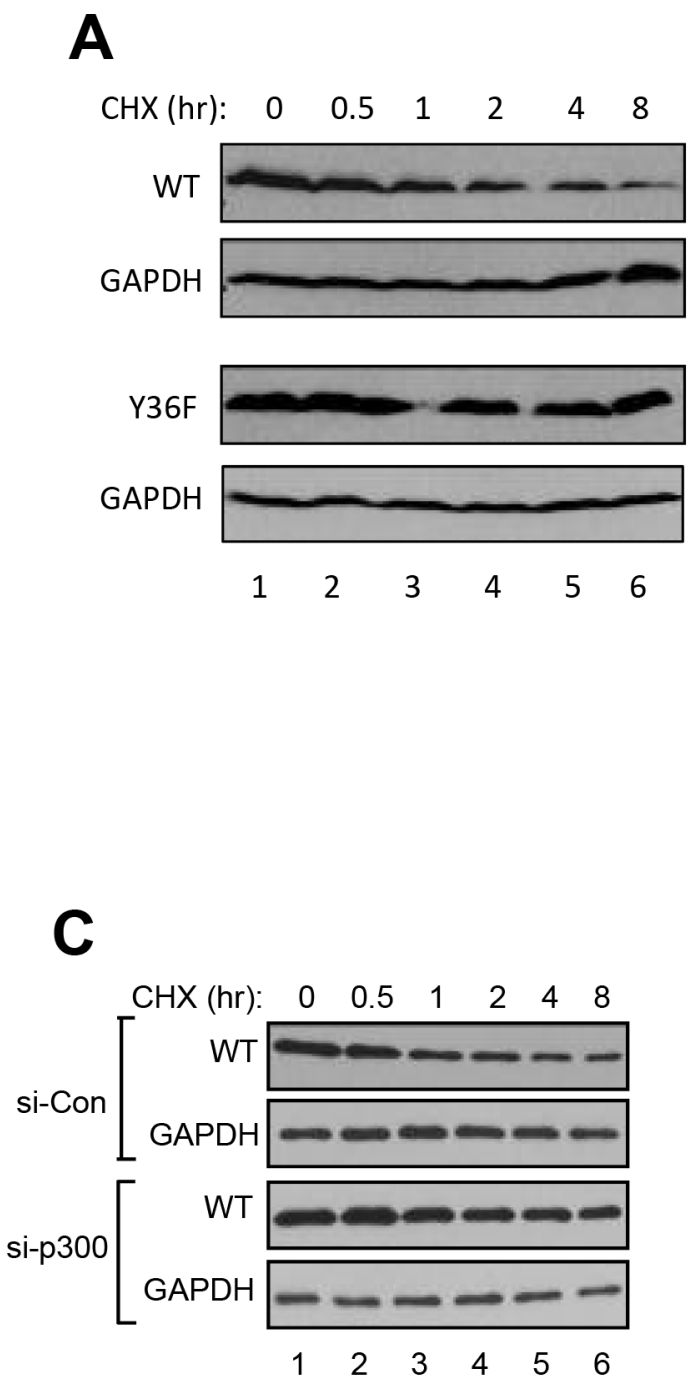

AF1 domain containing the phosphotyrosine residue yet have distinct biological activities from ER $\beta 1$. It will be important to determine in future studies whether the same phosphotyrosine switch regulates the functions of these variants.

Our current work significantly extends mechanistic insights into the pY36-dependent regulation of ER $\beta$ transcriptional activity. In particular, the dual effects of the phosphotyrosine switch on ER $\beta$-mediated transcriptional activation and ER $\beta$ turnover is reminiscent of accumulating reports of transcription-coupled ubiquitination and proteasome-mediated degradation of transcription factors [37, 38]. For example, the turnover of both $\mathrm{ER} \alpha$ and its coactivator SRC3/AIB1 is coupled to their actions in transcriptional activation [45-47]. It remains to be determined whether pY36-
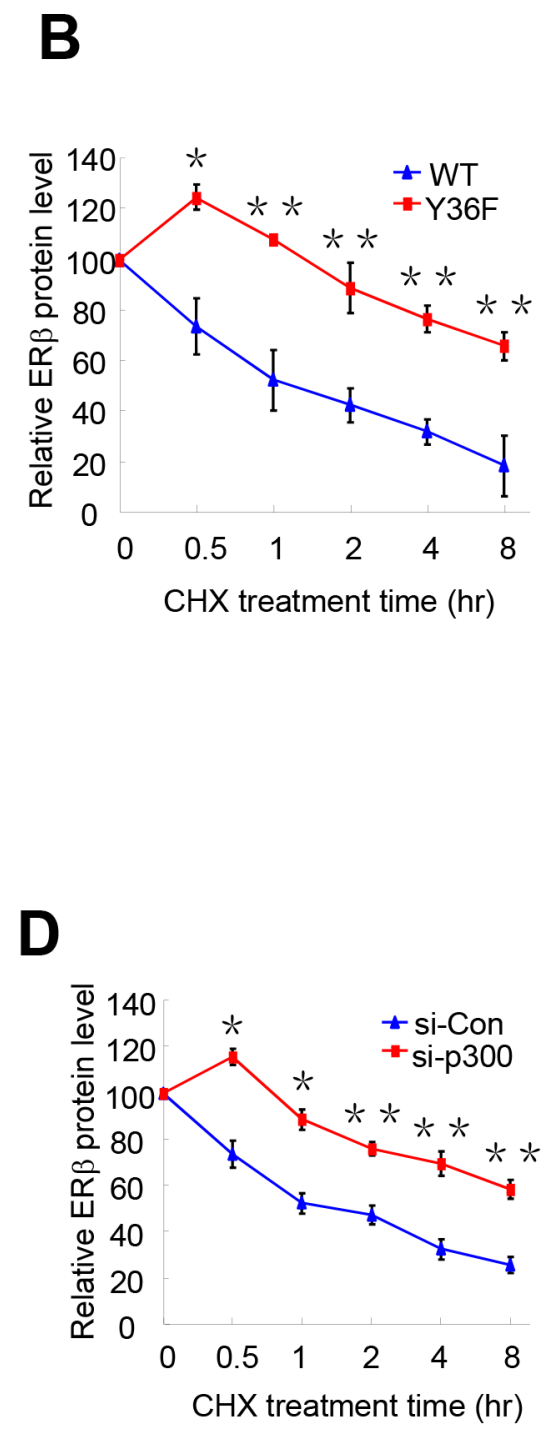

Figure 3: pY36 facilitates ER $\beta$ protein turnover. A. and B. The half-lives of WT-ER $\beta$ and Y36F-mutant proteins were analyzed. HEK293T cells were transfected with plasmids encoding WT-ER $\beta$ or Y36F mutant. Cells were treated with cycloheximide (CHX) 24 $\mathrm{h}$ after transfection and collected at the indicated time points. The results were quantitated using Image J software. C. and D. WT-ER $\beta$ plasmid was co-transfected with si-Con or si-p300 oligos into HEK293T cells for $48 \mathrm{~h}$. Transfected cells were subsequently treated with CHX for the indicated time. 
A

\section{WT Mut2}
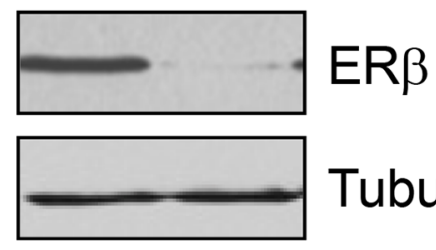

\section{Tubulin}

C
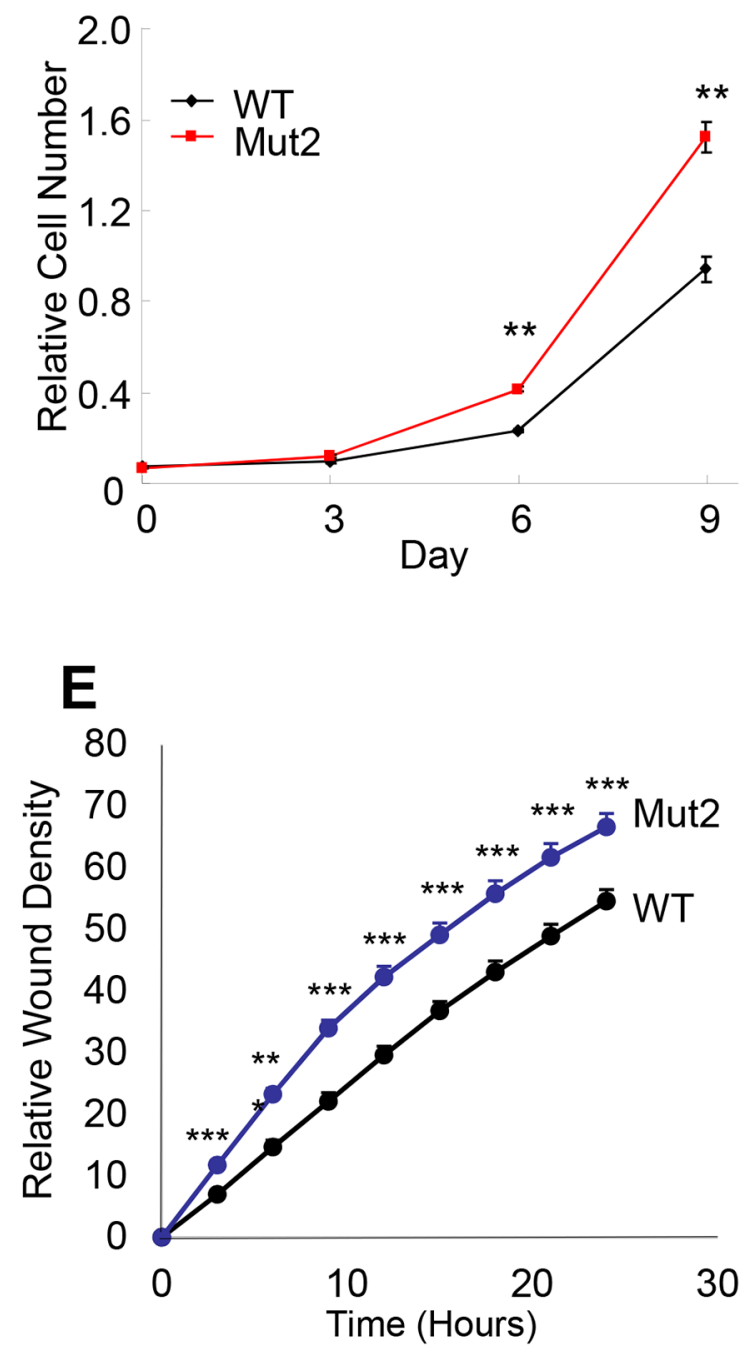

B

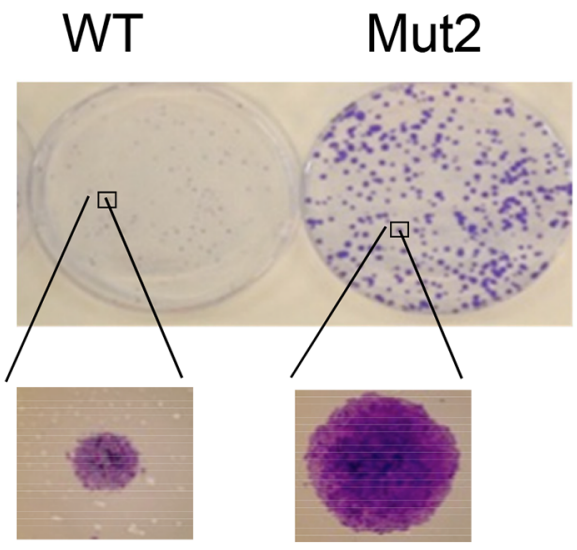

D

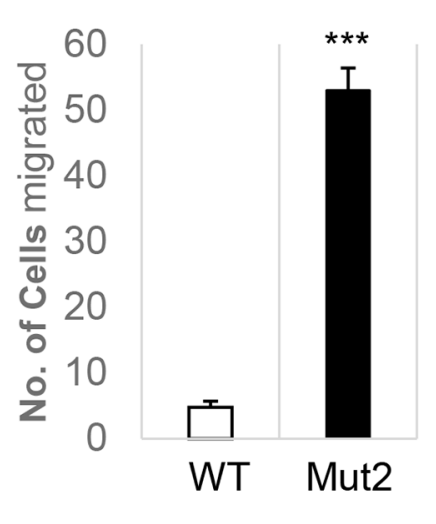

F

1.2

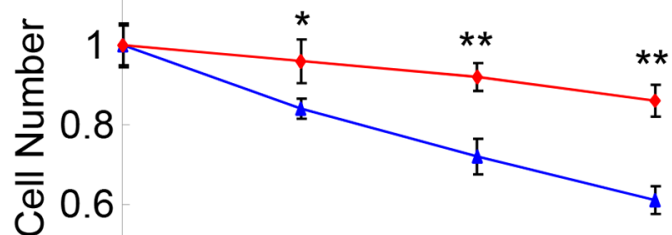

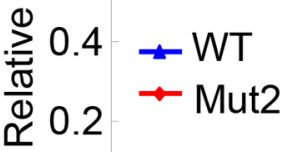

$0 \quad 10 \quad 50 \quad 100$

Figure 4: Endogenous ERß exhibits antitumor activity. A. CRISPR/Cas9 genome editing of ER $\beta$-encoding ESR2 gene in MDAMB-231 breast cancer cells. Western blot of ER $\beta$ in MDA-MB-231 cells and one ER $\beta$-edited clone (Mut2). B. ER $\beta$ KO cells have enhanced colony-forming ability versus parental cells. C. ER $\beta$ KO cells exhibit accelerated cell growth. D. KO cells displays increased migratory ability in a Boyden chamber assay. E. Increased cell migration as assessed in a wound-healing assay. F. ER $\beta$ KO cells are more refractory to ER $\beta$-selective agonist S-equol than parental cells. ${ }^{*} \mathrm{p}<0.05,{ }^{*} \mathrm{p}<0.01 .{ }^{* * *} \mathrm{p}<0.001$. 
dependent ubiquitination of ER $\beta$ occurs on chromatin and subsequent to coactivator recruitment. However, we favor the promoter-specific model, as Y36F mutation or overexpression of its corresponding phosphatase EYA2 increases chromatin occupancy of ER $\beta$ at ER $\beta$ - specific target promoters [34]. Such an activation-suicide process could ensure a rapid response of the transcription apparatus to fluctuating levels of estrogens and ER $\beta$ specific stimuli $[37,38]$. Alternatively, destruction of ER $\beta$ may be an obligatory part of transcriptional activation,
A

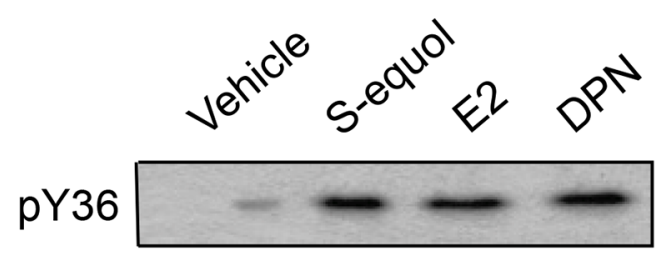

Total

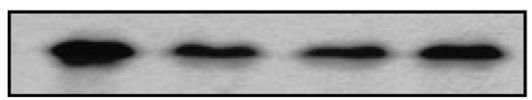

$\mathbf{B}$

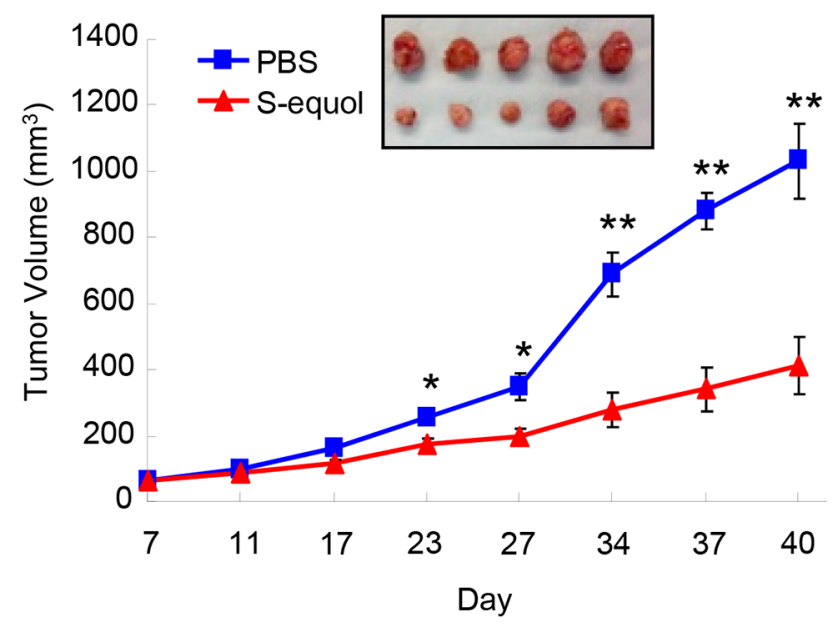

D

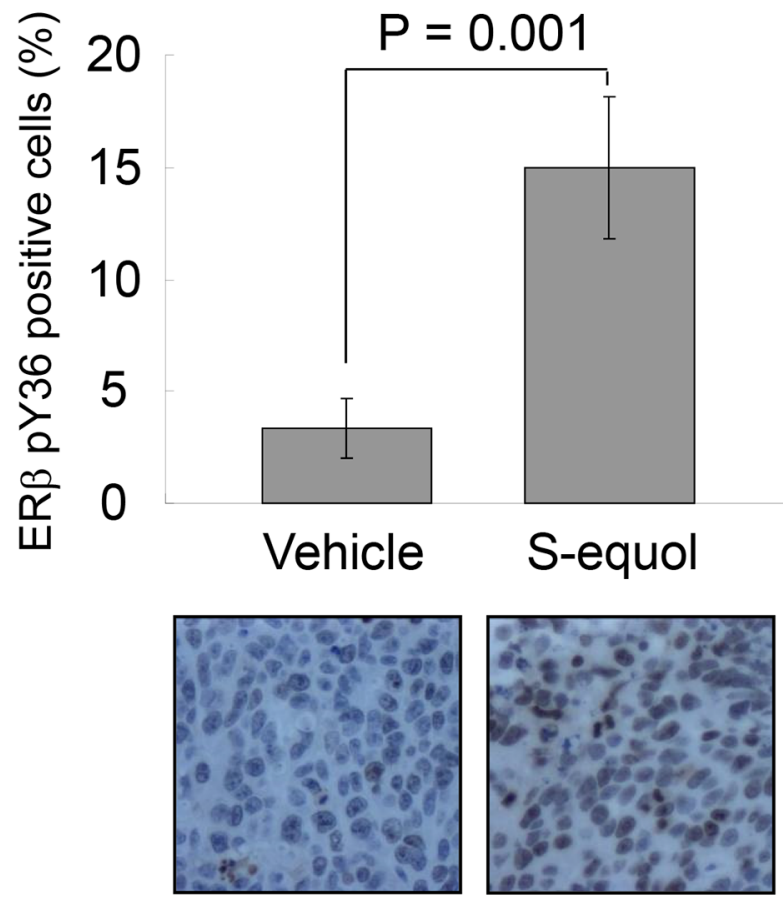

Figure 5: S-equol stimulates pY36 and inhibits tumor growth in vivo. A. pY36-specific phosphorylation signal was enhanced by the ER $\alpha / E R \beta$ common agonist $17-\beta$-estradiol and two ER $\beta$-specific agonists DPN and S-equol in MDA-MB-231 cells. B. S-equol treatment inhibited MDA-MB-231 cell-derived xenograft tumor growth $(n=5)$. C. Expression of Ki-67 in xenograft tumors. D. ER $\beta$-pY36 signal in vehicle- and S-equol-treated xenograft tumor samples. ${ }^{*} \mathrm{p}<0.05, * * \mathrm{p}<0.01$. 
without which the apparatus would be prevented from proceeding to the subsequent steps of transcription [38]. Regardless of the extent of transcription-ubiquitination coupling, the pY36-dependent functional reciprocity between ER $\beta$ and its coactivators likely results in active transcription of ER $\beta$ target genes and ultimately inhibition of tumor cell growth (Figure 6).

A number of clinically safe natural and synthetic compounds that function as ER $\beta$-selective agonists have been identified [48]. For example, a synthetic ER $\beta$ selective agonist LY500307 is being clinically tested for

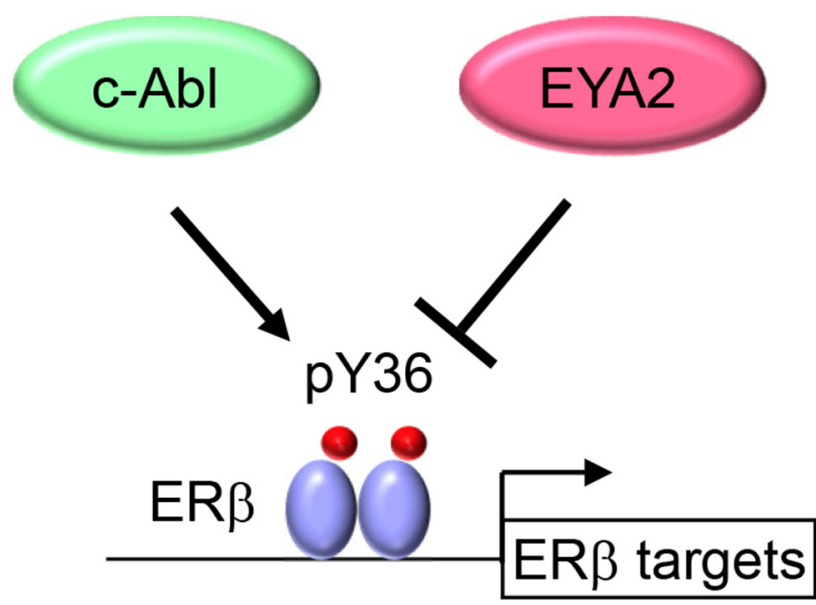

I

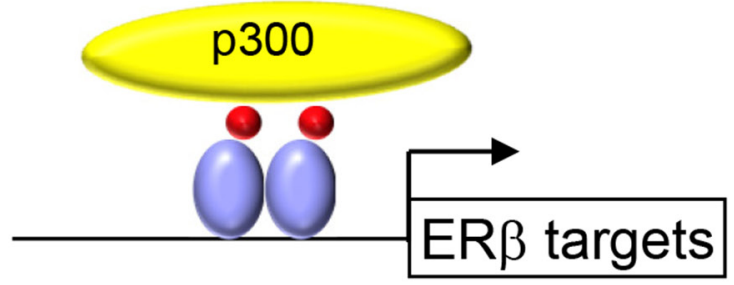

I

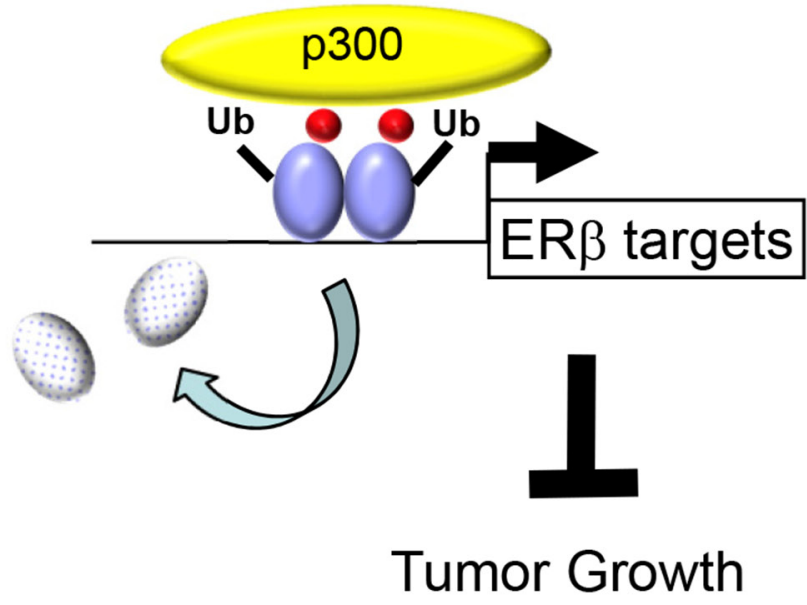

Figure 6: Model for transcription-coupled ER $\beta$ degradation. 
benign prostatic hyperplasia (BPH) and schizophrenia [49]. In addition, S-equol is clinically safe and well tolerated in humans, based on multiple phase I and II clinical trials [50-53]. As these compounds likely have additional targets in vivo besides ER $\beta$, it is critical to distinguish their ER $\beta$-dependent and -independent effects. The differential effects of S-equol on the proliferation of parental and ER $\beta$ knockout tumor cells observed in the current work strongly suggest that the antiproliferative action of S-equol is at least partly mediated by ER $\beta$. Our findings are also consistent with previously reported antitumor effect of S-equol on MCF7-derived xenografted tumors [54]. Of note, stimulation of ER $\beta$ phosphorylation by S-equol observed both in vitro and in vivo raises the distinct possibility of crosstalk between ligand- and posttranslational modification-dependent activation of ER $\beta$. While the exact mechanism underlying the $\mathrm{N}-(\mathrm{AF} 1)$ and C-terminal (AF2) crosstalk awaits future investigation, we speculate that this could be mediated by transcriptional coactivators that interact with both ER $\beta$ activation domains. Of note, previous studies of ER $\alpha$ suggest functional communications between AF1 and AF2 activation domains in ER $\alpha$-mediated transcriptional activation and biological functions in vivo [55-60]. We therefore envision that simultaneous targeting of ER $\beta$ tyrosine phosphorylation and ligand binding could achieve maximal activity of ER $\beta$ for treating those $E R \beta$-expressing cancers with an intact pY36 signaling circuitry. In summary, ER $\beta$-selective agonists, together with the known kinase and phosphatase targeting this switch, provide multiple novel and druggable targets for activating the subtype-specific function of ER $\beta$.

\section{MATERIALS AND METHODS}

\section{Cell lines and reagents}

The expression vectors for WT and mutant ER $\beta$ were described previously [34]. The plasmid for p300 expression was kindly provided by Dr. Zhi-Min Yuan (Harvard T.H. Chan School of Public Health). Cell lines were originally purchased from the American Type Culture Collection and cultured per their instructions.17$\beta$-estradiol (E2), DPN, and MG132 were obtained from Tocris, Inc. S-equol was generously provided by Ausio Pharmaceuticals. The following antibodies were purchased commercially: anti-Flag M2 (A8592 and F3165, SigmaAldrich), anti-ER $\beta$ for immunoblotting (14C8, GeneTex; 9.88, Abcam), anti-ER $\beta$ for immunoprecipitation (IP) (EPR3777, Novus), anti-p300 (sc-584, Santa Cruz Biotechnology Inc.), anti-GAPDH (G9295, SigmaAldrich), anti-FLAG-HRP (A8592, Sigma-Aldrich), anti-Flag M2 agarose (A2220, Sigma-Aldrich), and antiKi67 (GTX16667, GeneTex).The rabbit polyclonal antipY36 antibody was raised as previously described [34]. Oligonucleotides si-Con (non-targeting) (L-001810-10), si-p300 (L-003486-00), ON-TARGETplus smart pool siRNA duplexes were purchased from Dharmacon.

\section{MTT assay}

Cell viability was measured by the MTT (3-(4,5-dimethylthiazol-2-yl)-2,5-diphenyltetrazolium bromide) using the manufacturer's protocol (ATCC). Briefly, cells were plated in 96-well microtiter plates, allowed to attach overnight, and treated with concentrations of S-equol as indicated for $72 \mathrm{~h}$ at $37^{\circ} \mathrm{C}$. MTT was added to the culture medium to yield a final concentration of $0.5 \mathrm{mg} / \mathrm{ml}$ following cell treatment, and the incubation was continued for $1 \mathrm{~h}$ at $37^{\circ} \mathrm{C}$. The pellets were dissolved with dimethyl sulfoxide at room temperature for $10 \mathrm{~min}$. Cell viability was determined by measuring the absorbance of the converted dye at a wave length of $570 \mathrm{~nm}$.

\section{Cell migration/invasion assays}

For assessing MCF7 cell migration, cells were grown to $80 \%$ confluence and harvested from the plate using $0.05 \%$ trypsin-EDTA. Cells were collected, washed with serum-free medium twice, and resuspended in serumfree medium. Twenty-four-well transwell chambers (BD BioCoat Cat.\# 354575) with $8.0 \mu \mathrm{m}$ pore size polycarbonate membranes were used. Cells were plated at $1 \times 10^{5}$ cells/well in $0.5 \mathrm{~mL}$ in the inserts, which were then placed into chambers containing growth medium with $10 \% \mathrm{FBS}$. After incubation at $37^{\circ} \mathrm{C}$, for $24 \mathrm{~h}$, inserts were removed and cells were fixed in $4 \%$ paraformaldehyde and stained with $0.1 \%$ crystal-violet. Cells on the upper membrane surface were removed with a cotton swab. Airdried membranes were viewed under $10 \mathrm{x}$ magnification and migrated cells were counted in five randomly chosen fields/membrane. Each cell line was assayed at least 3 times and assays were performed in duplicate. Error bars show s.e.m. For invasion assays, Matrigel-coated inserts with $8.0 \mu \mathrm{m}$ pore size membranes (BD BioCoat Cat.\# 354480) were used.

For assessing MDA-MB-231 cell migration, cells were grown to $80 \%$ confluency, serum-starved for $3 \mathrm{~h}$, and then harvested from the plate using $0.05 \%$ trypsin-EDTA. Cells were seeded at $5 \times 10^{4}$ cells $/ 200 \mu \mathrm{l}$ of serum-free medium per insert, which were then placed into 24-well transwell chambers (BD BioCoat Cat.\# 354575, $8.0 \mu \mathrm{m}$ pore size), containing growth medium with $10 \%$ FBS. After incubation at $37^{\circ} \mathrm{C}$ for $4 \mathrm{~h}$, the cells were fixed and processed as mentioned above. For the wound-healing assay, cells were seeded in 96-well image lock plate (Essen BioScience Cat.\#4379) in triplicates, at 70,000 cells/well in growth medium with $10 \%$ FBS. After incubation at $37^{\circ} \mathrm{C}$ for $6 \mathrm{~h}$, a scratch was made and wound healing was assessed in time lapse for $24 \mathrm{~h}$ using IncuCyte Live-Cell Imaging System (IncuCyte ZOOM ${ }^{\circledR}$, Essen Bioscience Inc.). 


\section{In vitro ubiquitination assay}

Recombinant His-ER $\beta$ or GST-p300(1-595) was constructed, expressed and purified from E.coli BL21 cells expressing PET32a-ER $\beta$ or GST-p300(1-595) according to the manufactures' instructions (Qiagen and Amersham). Myc-p300(1-595) protein immunoprecipitates were immunoprecipitated with Myc beads from 293T cells transfected with Myc-p300(1-595) and eluted with a Myc peptide. In vitro ubiquitination assays were performed in ubiquitination reaction buffer ( $25 \mathrm{mM}$ Hepes $\mathrm{pH} 7.4,10$ $\mathrm{mM} \mathrm{NaCl}, 3 \mathrm{mM} \mathrm{MgCl} 2,0.05 \%$ Triton X-100, $0.5 \mathrm{mM}$ DTT, 3 mM Mg-ATP (B-20, Boston Biochem)) with 100 ng E1 (E-305, Boston Biochem), 50 ng E2 (ubch5a, E2616, Boston Biochem), $5 \mu \mathrm{g}$ ubiquitin (Ub, U-100Pf, Boston Biochem), and were incubated for $60 \mathrm{~min}$ at $37^{\circ} \mathrm{C}$. The samples were subjected to SDS-PAGE and analyzed with indicated antibodies.

\section{In vivo ubiquitination assay}

293 T cells were transfected with WT or mutant ER $\beta$. Twenty-four $h$ after transfection, cells were reseeded and transfected with control siRNA or p300 siRNA with Lipofectamine RNAiMAX transfection reagent (Invitrogen). Two days following transfection, cells were treated with MG132 $(5 \mu \mathrm{M})$ for $6 \mathrm{~h}$. Immunoprecipitation was performed as previously described [61].

\section{Protein half-life assay}

HEK293T cells were transfected with WT and mutant ER $\beta .24 \mathrm{~h}$ after transfection, fresh medium containing cycloheximide (Sigma) was added to a final concentration of $50 \mu \mathrm{M}$. Cells were harvested at indicated time points. ER $\beta$ steady-state levels were analyzed by Western blotting. Each result was derived from at least three independent experiments assessing densitometrybased protein ER $\beta$ quantification using GAPDH as the internal control.

\section{Ligand treatment}

For ligand stimulation, cells were cultured in phenol red-free medium containing 5\% charcoal stripped (CS) FBS for 3 days, re-seeded in Nunclon plates, and transfected with various vectors as indicated with Lipofectamine 2000 (Invitrogen). Six h after transfection, cells were treated with either vehicle or ligand at the indicated final concentration.

\section{Generation of ERß CRISPR knockout cells}

ER $\beta$ specific sgRNA target sequences were cloned into the CRISPR v2 vector (Addgene plasmid \#52961). The 20-bp target sequences of the indicated sgRNAs were as follows: $\operatorname{sgER} \beta-1$, GGATTGACTGCAGTTGTAGG;
sgER $\beta-2$, GAAGGAGAATTAAGGCTAGA. Three days after transfection, cells were selected with puromycin (Sigma) at $1 \mu \mathrm{g} / \mathrm{ml}$ for 3 weeks. Genomic DNA was extracted using the PureLink Genomic DNA Mini Kit (K1820-00, Life Technologies) according to the manufacturer's instructions. Drug-resistant cell clones were propagated and screened for mutations at nuclease target sites by PCR amplification of genomic sequences followed by DNA sequencing.

\section{Xenografts}

All animal experiments were performed after obtaining University od Texas Health Science Center at San Antonio (UTHSCSA) IACUC approval, and all methods were carried out in accordance with the IACUC approved guidelines. $5 \times 10^{6}$ MDA-MB-231 cells were injected orthotopically into mammary gland fat pads of 6 week-old female athymic nude mice (Harlan). When the tumor masses reached 50 to $80 \mathrm{~mm}^{3}$ (about one week after the inoculation), the mice were given daily subcutaneous injections of S-equol $(20 \mathrm{mg} / \mathrm{kg}$ per day) or PBS as a vehicle control. Tumor development was followed by caliper measurements along two orthogonal axes: length $(\mathrm{L})$ and width $(\mathrm{W})$ and volume $(\mathrm{V})$ was estimated by the formula $\mathrm{V}=\left[\mathrm{Lx}\left(\mathrm{W}^{2}\right)\right] / 2$.

\section{Immunohistochemistry}

Xenograft tumors harvested from mice were fixed in $10 \%$ neutral-buffered formalin, dehydrated, embedded in paraffin, and sectioned at $3 \mu \mathrm{m}$ thickness. Representative tumor sections from vehicle control and S-equol-treated mice were tested for Ki-67 expression to assess cell proliferation, and for $\mathrm{ER} \beta \mathrm{pY} 36$.

\section{Statistics}

Statistical significance in the experiments was assessed by two-tailed Student's $t$ test. In all assays, $\mathrm{p}<$ 0.05 was considered statistically significant.

\section{ACKNOWLEDGMENTS}

We thank Ms. Sabrina Smith for technical support, Dr. Zhi-Min Yuan for providing p300 plasmid, and Ausio Pharmaceuticals for the generous gift of S-equol. The work was supported by grants to Q.Y. from National Natural Science Foundation (81330053 and 81272913) and the China Major State Basic Research Development Program (2012CB945100); a grant from Beijing Nova Program (Z131102000413034) to L.C., a predoctoral training grant to B.Y. and a postdoctoral training grant to K.G. from Cancer Prevention and Research Institute of Texas (RP 140105); grants to R.L. from NIH (CA161349, LM010212, and UL1 TR001120), Cancer Prevention and Research Institute of 
Texas (DP150055 and RP150574), and the Tom C. \& H. Frost Endowment; grants to T. C. from the Congressionally Directed Medical Research Program (OC140355), The Owens Foundation, The Barker Foundation and The Skinner Endowment) and the Cancer Therapy and Research Center at University of Texas Health Science Center at San Antonio (P30CA054174).

\section{CONFLICTS OF INTEREST}

The authors have no conflicts of interest to disclose.

\section{REFERENCES}

1. Thomas C, Gustafsson JA. The different roles of ER subtypes in cancer biology and therapy. Nat Rev Cancer. 2011; 11:597-608.

2. Bossard C, Busson M, Vindrieux D, Gaudin F, Machelon V, Brigitte M, Jacquard C, Pillon A, Balaguer P, Balabanian $\mathrm{K}$, Lazennec G. Potential role of estrogen receptor beta as a tumor suppressor of epithelial ovarian cancer. PloS one. 2012; 7:e44787.

3. Cho JL, Allanson M, Reeve VE. Oestrogen receptor-beta signalling protects against transplanted skin tumour growth in the mouse. Photochem Photobiol Sci. 2010; 9:608-614.

4. Sareddy GR, Nair BC, Gonugunta VK, Zhang QG, Brenner A, Brann DW, Tekmal RR, Vadlamudi RK. Therapeutic significance of estrogen receptor beta agonists in gliomas. Mol Cancer Ther. 2012; 11:1174-1182.

5. Hodges-Gallagher L, Valentine CD, El Bader S, Kushner PJ. Estrogen receptor beta increases the efficacy of antiestrogens by effects on apoptosis and cell cycling in breast cancer cells. Breast Cancer Res Treat. 2008; 109:241-250.

6. Strom A, Hartman J, Foster JS, Kietz S, Wimalasena J, Gustafsson JA. Estrogen receptor beta inhibits 17betaestradiol-stimulated proliferation of the breast cancer cell line T47D. Proc Natl Acad Sci U S A. 2004; 101:1566-1571.

7. Hartman J, Lindberg K, Morani A, Inzunza J, Strom A, Gustafsson JA. Estrogen receptor beta inhibits angiogenesis and growth of T47D breast cancer xenografts. Cancer Res. 2006; 66:11207-11213.

8. Monroe DG, Getz BJ, Johnsen SA, Riggs BL, Khosla S, Spelsberg TC. Estrogen receptor isoform-specific regulation of endogenous gene expression in human osteoblastic cell lines expressing either ERalpha or ERbeta. J Cell Biochem. 2003; 90:315-326.

9. Kian Tee M, Rogatsky I, Tzagarakis-Foster C, Cvoro A, An J, Christy RJ, Yamamoto KR, Leitman DC. Estradiol and selective estrogen receptor modulators differentially regulate target genes with estrogen receptors alpha and beta. Mol Biol Cell. 2004; 15:1262-1272.
10. Stossi F, Barnett DH, Frasor J, Komm B, Lyttle CR, Katzenellenbogen BS. Transcriptional profiling of estrogenregulated gene expression via estrogen receptor (ER) alpha or ERbeta in human osteosarcoma cells: distinct and common target genes for these receptors. Endocrinology. 2004; 145:3473-3486.

11. Secreto FJ, Monroe DG, Dutta S, Ingle JN, Spelsberg TC. Estrogen receptor alpha/beta isoforms, but not betacx, modulate unique patterns of gene expression and cell proliferation in Hs578T cells. J Cell Biochem. 2007; 101:1125-1147.

12. Hawse JR, Subramaniam M, Monroe DG, Hemmingsen $\mathrm{AH}$, Ingle JN, Khosla S, Oursler MJ, Spelsberg TC. Estrogen receptor beta isoform-specific induction of transforming growth factor beta-inducible early gene-1 in human osteoblast cells: an essential role for the activation function 1 domain. Mol Endocrinol. 2008; 22:1579-1595.

13. Paruthiyil S, Cvoro A, Zhao X, Wu Z, Sui Y, Staub RE, Baggett S, Herber CB, Griffin C, Tagliaferri M, Harris HA, Cohen I, Bjeldanes LF, Speed TP, Schaufele F, Leitman DC. Drug and cell type-specific regulation of genes with different classes of estrogen receptor beta-selective agonists. PLoS One. 2009; 4:e6271.

14. Chang EC, Frasor J, Komm B, Katzenellenbogen BS. Impact of estrogen receptor beta on gene networks regulated by estrogen receptor alpha in breast cancer cells. Endocrinology. 2006; 147:4831-4842.

15. Charn TH, Liu ET, Chang EC, Lee YK, Katzenellenbogen JA, Katzenellenbogen BS. Genome-wide dynamics of chromatin binding of estrogen receptors alpha and beta: mutual restriction and competitive site selection. Mol Endocrinol. 2010; 24:47-59.

16. Vivar OI, Zhao X, Saunier EF, Griffin C, Mayba OS, Tagliaferri M, Cohen I, Speed TP, Leitman DC. Estrogen receptor beta binds to and regulates three distinct classes of target genes. J Biol Chem. 2010; 285:22059-22066.

17. Zhao C, Gao H, Liu Y, Papoutsi Z, Jaffrey S, Gustafsson JA, Dahlman-Wright K. Genome-wide mapping of estrogen receptor-beta-binding regions reveals extensive cross-talk with transcription factor activator protein-1. Cancer Res. 2010; 70:5174-5183.

18. Jiang Y, Gong P, Madak-Erdogan Z, Martin T, Jeyakumar M, Carlson K, Khan I, Smillie TJ, Chittiboyina AG, Rotte SC, Helferich WG, Katzenellenbogen JA, Katzenellenbogen BS. Mechanisms enforcing the estrogen receptor beta selectivity of botanical estrogens. FASEB J. 2013; 27:4406-4418.

19. Shanle EK, Zhao Z, Hawse J, Wisinski K, Keles S, Yuan M, $\mathrm{Xu}$ W. Research resource: global identification of estrogen receptor beta target genes in triple negative breast cancer cells. Mol Endocrinol. 2013; 27:1762-1775.

20. Sun J, Meyers MJ, Fink BE, Rajendran R, Katzenellenbogen JA, Katzenellenbogen BS. Novel ligands that function as selective estrogens or antiestrogens for estrogen 
receptor-alpha or estrogen receptor-beta. Endocrinology. 1999; 140:800-804.

21. Paruthiyil S, Parmar H, Kerekatte V, Cunha GR, Firestone GL, Leitman DC. Estrogen receptor beta inhibits human breast cancer cell proliferation and tumor formation by causing a G2 cell cycle arrest. Cancer Res. 2004; 64:423-428.

22. Williams C, Edvardsson K, Lewandowski SA, Strom A, Gustafsson JA. A genome-wide study of the repressive effects of estrogen receptor beta on estrogen receptor alpha signaling in breast cancer cells. Oncogene. 2008; 27:1019-1032.

23. Frasor J, Chang EC, Komm B, Lin CY, Vega VB, Liu ET, Miller LD, Smeds J, Bergh J, Katzenellenbogen BS. Gene expression preferentially regulated by tamoxifen in breast cancer cells and correlations with clinical outcome. Cancer Res. 2006; 66:7334-7340.

24. Chang EC, Charn TH, Park SH, Helferich WG, Komm B, Katzenellenbogen JA, Katzenellenbogen BS. Estrogen Receptors alpha and beta as determinants of gene expression: influence of ligand, dose, and chromatin binding. Mol Endocrinol. 2008; 22:1032-1043.

25. Deroo BJ, Buensuceso AV. Minireview: Estrogen receptorbeta: mechanistic insights from recent studies. Mol Endocrinol. 2010; 24:1703-1714.

26. Pettersson K, Grandien K, Kuiper GG, Gustafsson JA. Mouse estrogen receptor beta forms estrogen response element-binding heterodimers with estrogen receptor alpha. Mol Endocrinol. 1997; 11:1486-1496.

27. Cowley SM, Hoare S, Mosselman S, Parker MG. Estrogen receptors alpha and beta form heterodimers on DNA. J Biol Chem. 1997; 272:19858-19862.

28. Tremblay GB, Tremblay A, Labrie F, Giguere V. Dominant activity of activation function 1 (AF-1) and differential stoichiometric requirements for $\mathrm{AF}-1$ and -2 in the estrogen receptor alpha-beta heterodimeric complex. Mol Cell Biol. 1999; 19:1919-1927.

29. Hall JM, McDonnell DP. The estrogen receptor betaisoform (ERbeta) of the human estrogen receptor modulates ERalpha transcriptional activity and is a key regulator of the cellular response to estrogens and antiestrogens. Endocrinology. 1999; 140:5566-5578.

30. Li X, Huang J, Yi P, Bambara RA, Hilf R, Muyan M. Single-chain estrogen receptors (ERs) reveal that the ERalpha/beta heterodimer emulates functions of the ERalpha dimer in genomic estrogen signaling pathways. Mol Cell Biol. 2004; 24:7681-7694.

31. Paulmurugan R, Tamrazi A, Massoud TF, Katzenellenbogen JA, Gambhir SS. In vitro and in vivo molecular imaging of estrogen receptor alpha and beta homo- and heterodimerization: exploration of new modes of receptor regulation. Mol Endocrinol. 2011; 25:2029-2040.
32. Smith CL, O'Malley B. Coregulator function: a key to understanding tissue specificity of selective receptor modulators. Endocr Rev. 2004; 25:45-71.

33. Madak-Erdogan Z, Charn TH, Jiang Y, Liu ET, Katzenellenbogen JA, Katzenellenbogen BS. Integrative genomics of gene and metabolic regulation by estrogen receptors alpha and beta, and their coregulators. Mol Syst Biol. 2013; 9:676.

34. Yuan B, Cheng L, Chiang HC, Xu X, Han Y, Su H, Wang L, Zhang B, Lin J, Li X, Xie X, Wang T, Tekmal RR, Curiel TJ, Yuan ZM, Elledge R, et al. A phosphotyrosine switch determines the antitumor activity of ERbeta. J Clin Invest. 2014; 124:3378-3390.

35. Gallo D, De Stefano I, Grazia Prisco M, Scambia G, Ferrandina G. Estrogen receptor beta in cancer: an attractive target for therapy. Curr Pharm Des. 2012; 18:2734-2757.

36. Lam HM, Suresh Babu CV, Wang J, Yuan Y, Lam YW, Ho SM, Leung YK. Phosphorylation of human estrogen receptor-beta at serine 105 inhibits breast cancer cell migration and invasion. Molecular and cellular endocrinology. 2012; 358:27-35.

37. Conaway RC, Brower CS, Conaway JW. Emerging roles of ubiquitin in transcription regulation. Science. 2002; 296:1254-1258.

38. Geng F, Wenzel S, Tansey WP. Ubiquitin and proteasomes in transcription. Annual review of biochemistry. 2012; 81:177-201.

39. Tateishi Y, Sonoo R, Sekiya Y, Sunahara N, Kawano M, Wayama M, Hirota R, Kawabe Y, Murayama A, Kato S, Kimura K, Yanagisawa J. Turning off estrogen receptor beta-mediated transcription requires estrogen-dependent receptor proteolysis. Molecular and cellular biology. 2006; 26:7966-7976.

40. Picard N, Charbonneau C, Sanchez M, Licznar A, Busson M, Lazennec G, Tremblay A. Phosphorylation of activation function-1 regulates proteasome-dependent nuclear mobility and E6-associated protein ubiquitin ligase recruitment to the estrogen receptor beta. Mol Endocrinol. 2008; 22:317-330.

41. Grossman SR, Deato ME, Brignone C, Chan HM, Kung AL, Tagami H, Nakatani Y, Livingston DM. Polyubiquitination of p53 by a ubiquitin ligase activity of p300. Science. 2003; 300:342-344.

42. Marotti JD, Collins LC, Hu R, Tamimi RM. Estrogen receptor-beta expression in invasive breast cancer in relation to molecular phenotype: results from the Nurses' Health Study. Modern Pathology. 2010; 23:197-204.

43. Reese JM, Suman VJ, Subramaniam M, Wu X, Negron V, Gingery A, Pitel KS, Shah SS, Cunliffe HE, McCullough AE, Pockaj BA, Couch FJ, Olson JE, Reynolds C, Lingle WL, Spelsberg TC, et al. ERbeta1: characterization, prognosis, and evaluation of treatment strategies in ERalpha-positive and -negative breast cancer. BMC Cancer. 2014; $14: 749$. 
44. Nilsson S, Koehler KF, Gustafsson JA. Development of subtype-selective oestrogen receptor-based therapeutics. Nat Rev Drug Discov. 2011; 10:778-792.

45. Lonard DM, Nawaz Z, Smith CL, O'Malley BW. The 26S proteasome is required for estrogen receptor-alpha and acoactivator turnover and for efficient estrogen receptoralpha transactivation. Mol Cell. 2000; 5:939-948.

46. Shao W, Keeton EK, McDonnell DP, Brown M. Coactivator AIB1 links estrogen receptor transcriptional activity and stability. Proceedings of the National Academy of Sciences of the United States of America. 2004; 101:11599-11604.

47. Li C, Liang YY, Feng XH, Tsai SY, Tsai MJ, O'Malley BW Essential phosphatases and a phospho-degron are critical for regulation of SRC-3/AIB1 coactivator function and turnover. Molecular cell. 2008; 31:835-849.

48. Warner M, Gustafsson JA. The role of estrogen receptor beta (ERbeta) in malignant diseases-a new potential target for antiproliferative drugs in prevention and treatment of cancer. Biochem Biophys Res Commun. 2010; 396:63-66.

49. Roehrborn CG, Spann ME, Myers SL, Serviss CR, Hu L, Jin Y. Estrogen receptor beta agonist LY500307 fails to improve symptoms in men with enlarged prostate secondary to benign prostatic hypertrophy. Prostate Cancer Prostatic Dis. 2015 ; 18:43-48.

50. Setchell KD, Clerici C, Lephart ED, Cole SJ, Heenan C, Castellani D, Wolfe BE, Nechemias-Zimmer L, Brown NM, Lund TD, Handa RJ, Heubi JE. S-equol, a potent ligand for estrogen receptor beta, is the exclusive enantiomeric form of the soy isoflavone metabolite produced by human intestinal bacterial flora. Am J Clin Nutr. 2005; 81:1072-1079.

51. Jackson RL, Greiwe JS, Schwen RJ. Emerging evidence of the health benefits of S-equol, an estrogen receptor beta agonist. Nutrition Rev. 2011; 69:432-448.

52. Ishiwata N, Melby MK, Mizuno S, Watanabe S. New equol supplement for relieving menopausal symptoms: randomized, placebo-controlled trial of Japanese women. Menopause. 2009; 16:141-148.

53. Jackson RL, Greiwe JS, Desai PB, Schwen RJ. Singledose and steady-state pharmacokinetic studies of S-equol, a potent nonhormonal, estrogen receptor beta-agonist being developed for the treatment of menopausal symptoms. Menopause. 2011; 18:185-193.
54. Onoda A, Ueno T, Uchiyama S, Hayashi S, Kato K, Wake $\mathrm{N}$. Effects of S-equol and natural S-equol supplement (SE5-OH) on the growth of MCF-7 in vitro and as tumors implanted into ovariectomized athymic mice. Food Chem Toxicol. 2011; 49:2279-2284.

55. Merot Y, Metivier R, Penot G, Manu D, Saligaut C, Gannon F, Pakdel F, Kah O, Flouriot G. The relative contribution exerted by AF-1 and AF-2 transactivation functions in estrogen receptor alpha transcriptional activity depends upon the differentiation stage of the cell. J Biol Chem. 2004; 279:26184-26191.

56. Chen A, Kleiman FE, Manley JL, Ouchi T, Pan ZQ. Autoubiquitination of the BRCA1*BARD1 RING ubiquitin ligase. J Biol Chem. 2002; 277:22085-22092.

57. Borjesson AE, Windahl SH, Lagerquist MK, Engdahl C, Frenkel B, Moverare-Skrtic S, Sjogren K, Kindblom JM, Stubelius A, Islander U, Antal MC, Krust A, Chambon P, Ohlsson C. Roles of transactivating functions 1 and 2 of estrogen receptor-alpha in bone. Proc Natl Acad Sci U S A. 2011; 108:6288-6293.

58. Shah SP, Roth A, Goya R, Oloumi A, Ha G, Zhao Y, Turashvili G, Ding J, Tse K, Haffari G, Bashashati A, Prentice LM, Khattra J, Burleigh A, Yap D, Bernard V, et al. The clonal and mutational evolution spectrum of primary triple-negative breast cancers. Nature. 2012; 486:395-399.

59. Arao Y, Coons LA, Zuercher WJ, Korach KS. Transactivation Function-2 of Estrogen Receptor alpha Contains Transactivation Function-1-regulating Element. J Biol Chem. 2015; 290:17611-17627.

60. Nwachukwu JC, Srinivasan S, Zheng Y, Wang S, Min J, Dong C, Liao Z, Nowak J, Wright NJ, Houtman R, Carlson KE, Josan JS, Elemento O, Katzenellenbogen JA, Zhou HB, Nettles KW. Predictive features of ligand-specific signaling through the estrogen receptor. Mol Syst Biol. 2016; 12:864.

61. Aiyar SE, Sun J-L, Blair AL, Moskaluk CA, Lv Y, Ye Q-N, Yamaguchi Y, Mukherjee A, Ren D-M, Handa H, Li R. Attenuation of estrogen receptor alpha-mediated transcription through estrogen-stimulated recruitment of a negative elongation factor. Genes \& Dev. 2004; 18:2134-2146. 